\title{
Öğretmen Adaylarının Kavram Yanılgılarının Üç Aşamalı Kavram Yanılgısı Testi ile Belirlenmesi
}

\author{
Determining Misconceptions of Prospective Teachers with the Three-Tier \\ Misconception Test
}

\author{
Doç. Dr. Rıdvan ELMAS (D) ${ }^{1}$, Dr. Savaş PAMUK (iD)2
}

\begin{abstract}
$\ddot{O} z$
Bu çalışmanın amacı fen bilimleri öğretmen adaylarının kavram yanılgılarını, üç aşamalı kavram yanılgısı testi ile belirlemektir. Bu amaçla fiziksel ve kimyasal değişimler konusunda alan yazından belirlenen yaygın 10 tane kavram yanılgısı seçilmiş ve hangilerine aday öğretmenlerin sahip olduğunu araştırılmıştır. Çalışmaya orta büyüklükte bir üniversitenin fen bilgisi öğretmenliği programında okuyan 163 fen bilgisi öğretmen adayı katılmıştır. Çalışmada veriler üç aşamalı bir kavram yanılgısı testi ile toplanmıştır. Üç aşamalı kavram yanılgısı testinin kullanılmasının amacı aday öğretmenlerin tahminlerinden kaynaklanan yanlış pozitif sonuçların önüne geçmek ve daha detaylı bir veri toplama süreci yürütmektir. Üç aşamalı kavram yanılgısı testinin birinci ve üçüncü bölümleri sorunun doğru cevabına göre objektif olarak sınıflandırılırken ikinci bölüm için geliştirilen dereceli puanlama anahtarına uygun şekilde betimsel olarak analiz edilmiştir. Çalışmanın bulgularına göre aday öğretmenlerin özellikle kimyasal değişimin net bir tanımını yapmada güçlük çektikleri söylenebilir. Aday öğretmenlerin alan yazında çok sık yer verilen bazı kavram yanılgılarına sahip oldukları belirlenmiştir. Ayrıca günlük hayata dair örneklerden hava yastığının şişmesi ve çaya limon sıkılması, fiziksel veya kimyasal değişim olarak sınıflandırılmada en çok hata yapılan örnekler olarak tespit edilmiştir.
\end{abstract}

Anahtar Kelimeler: Kavram yanılgısı, kimyasal değişim, fiziksel değişim, fen bilgisi öğretmen adayı

Makale Türü: Araştırma

\begin{abstract}
This study aims to determine which of the ten common misconceptions determined in the literature regarding physical and chemical changes are possessed by prospective teachers. One hundred sixty-three science teacher candidates studying in a medium-sized university's science teaching program participated in the study. The data were collected with a three-tier misconception test. The purpose of using the threetier misconception test is to prevent false-positive results arising from prospective teachers' predictions and to carry out a more detailed data collection process. While the first and third parts of the three-tier misconception test were graded objectively according to the correct answer, the second part was analyzed descriptively according to the developed rubric. According to the findings of the study, it can be said that prospective teachers have difficulty in making a clear definition of chemical change. It has been determined that prospective teachers still have some misconceptions that are frequently mentioned in the literature. Besides, it has been found that the most mistakes are made in classifying the samples, including daily life cases as physical or chemical. Examples of these are the inflation of the airbag and the squeezing of lemon into tea.
\end{abstract}

Keywords: Misconceptions, chemical change, physical change, pre-service science teacher

Paper Type: Research

\section{Giriş}

\footnotetext{
${ }^{1}$ Afyon Kocatepe Üniversitesi, Eğitim Fakültesi, relmas@aku.edu.tr

${ }^{2}$ Akdeniz Üniversitesi, Eğitim Fakültesi, savaspamuk@gmail.com
}

Atıf için (to cite): Elmas, R. \& Pamuk, S. (2021). Öğretmen adaylarının kavram yanılgılarının üç aşamalı kavram yanılgısı testi ile belirlenmesi. Afyon Kocatepe Üniversitesi Sosyal Bilimler Dergisi, 23(4), 1386-1403. 
Kavramlar, birçok öğretim programında anahtar unsur olarak yer almaktadırlar. Fen bilimlerinin öğretiminde de kavram öğretimi oldukça önemli bir husustur ve köşe taşı gibi düşünülebilir (Eggen ve Kauchak, 2004). Türk Dil Kurumunun tanımına göre kavram; bir nesnenin veya düşüncenin zihindeki soyut ve genel tasarımıdır. Başka bir tanıma göre kavram benzer özellikler taşıyan örneklerin tümüdür. Kavramın nesnel, ilişkisel, üst, alt, bağlantıll, kendiliğinden, kendiliğinden olmayan, günlük, bilimsel, betimsel, kuramsal, somut ve soyut olmak üzere farklı türleri de bulunmaktadır (Ergül, Sarıtaş ve Özcan, 2020). Nesnel kavramlar bireylerin çevrelerinde bulunan varlıkları ifade etmede kullandıkları kavramlardır. İlişkisel kavramlar ise nesnel kavramlar arası ilişkileri belirtmek amacıyla kullanılan kavramlardır. Örneğin su nesnel kavram iken buharlaşma ilişkisel kavramdır çünkü yoğun bir buharlaşma suyun 1sınması sonucu oluşur. Üst kavramlar bir alana ait olan tüm kavramları kapsar. Alt kavramlar da üst kavramların altında yer alan kavramları oluşturur. Ulaşım araçları üst kavram ise kara, hava, deniz ulaşım araçları alt kavramlardır.

Öğrenciler kavramları kendiliğinden veya kendilerinden bu konuda daha bilgili birinden öğrenebilirler. Kendiliğinden öğrenilmiş kavramlar çocuğun dış dünyayı anladığı kadarıyla yorumlamasıdır. Kendiliğinden öğrenilmeyen kavramlar ise başka bireyler tarafından çocuğa öğretilmiş kavramlardır. Günlük kavramlar çocukların okul dışı yaşantıları sonucu gelişen kavramlar iken bilimsel kavramlar belirli bir bilim dalı ile ilgili olarak okullarda sistematik ve aşamalı bir şekilde sunulan kavramlardır. Havanın bulutlu olduğunu gören birinin yağmur yağacak demesi günlük kavramlara örnek olarak verilirken asit yağmurlarının kimyasal reaksiyonlar sonucunda oluştuğunu söyleyebilmesi bilimsel kavramlara örnek olarak verilebilir.

Fen eğitimi odağında düşünecek olursak, kavramların bir kavramdan ötekine doğru hiyerarşik bir şekilde ilerlediğini görürüz. Genelde bu ilerleme basitten karmaşığa, somuttan soyuta doğrudur. Fen bilimleri derslerinin içeriğinde somut ve soyut birçok kavram bulunmaktadır. Somut olan kavramların öğretimi deney ve gözlem yolu ile sağlanabilirken soyut olan kavramların öğretimi kısmen daha zor olmaktadır. Soyut kavramların öğretiminde kavram haritaları, artırılmış gerçeklik (AG), animasyonlar, infografikler, videolar ve benzeri araçlar kullanılarak desteklenmesi tavsiye edilir. Buna rağmen her iki tip kavram ile ilgili kavram yanılgıları oluşabilmektedir (Papageorgiou, Stamovlasis ve Johnson, 2010). Kavram yanılgısı, bireyin fen bilimlerindeki kavramların bilimsel ve doğru açıklaması dışında farklı bir şekilde açıklamasıdır (Treagust, 1988). Başka bir tanıma göre kavram yanılgısı kişilerin olaylar ve olgular hakkında bilimsel olarak tamamen yanlış olan fikir ve anlayışlarıdır (Chandrasegaran, Treagust ve Mocerino, 2007; Martin, Sexton ve Gerlovich, 2002). Bu açıklamalar kısmen doğru bilgiler ve veriler içerebilirler ama açıklama tümden ele alındığında bilimsel olarak yanlıştır (Bolat ve Dolapçığlu, 2020; Nakhleh, 1992). Alan yazında yer aldığı üzere kavram yanılgılarının ortaya çıkmasında birden fazla etken bulunmaktadır (Cho, Kahle ve Nordland, 1985; Taylor ve Kowalski, 2004).

Kavram yanılgıları öğretmen ya da öğrencilerde bulunan bilgi eksikliğinden kaynaklanabilir (Yates ve Marek, 2014; Yip, 1998). Örneğin, kaynama olayı sıvılar için ayırt edicidir ve belirli değerdedir ifadesi kaynama olayının sabit olduğunu çağrıştırabilir ve olayın dinamik yapısı öğrenci tarafından tam olarak anlaşılamayabilir. Somutlaştırma amaçlı deneylerin yapılmaması veya modellerin kullanılmaması da kavram yanılgılarının oluşma nedenlerinden biridir. Öğretmenlerin konuyu aşırı genelleme yaparak sunması da kavram yanılgilarına sebebiyet vermektedir.

Ders kitaplarında yer alan bazı ifadeler de kavram yanılgısı oluşturabilmektedir (Abimbola ve Baba, 1996; King, 2010). Bir diğer kavram yanılgısı nedeni ise öğretmen veya öğrencinin belki de net olarak açıklanmayan kavramlar üzerinden yanlış ilişkiler kurmasıdır (Şenel Çoruhlu ve Çepni, 2015). Bu duruma en iyi örnek erime ve çözünme kavramlarıdır (Nakiboğlu ve Erol, 2017). Kavram yanılgısının oluşmasını sağlayan diğer bir durum ise öğrencinin geçmiş yaşantısıdır (Kirbulut ve Geban, 2014). Örneğin mevsimlerin oluşumunu ögrenci yaz aylarında güneşin dünyaya yaklaşıp kış aylarında uzaklaşması olarak 
açılayabilmektedir. Bu duruma sebep olan eksen eğikliğini öğrencilere anlatmak ve öğrencileri ikna etmek oldukça güç olmaktadır çünkü öğrenci günlük hayatta bir 1sı kaynağına yaklaşırsa 1sınmakta uzaklaşırsa serinlemektedir (Sneider, Bar ve Kavanagh, 2011).

Öğrencilerin zihinlerinde var olan kavram yanılgıları daha sonraki dönemlerde öğrenecekleri bilgileri de etkilemektedir (Johnson, 1998a). Bu bağlamda kavram yanılgıları yeni bilgilerin öğrenilmesini karmaşık ve zor bir hale getirmektedir (Barke, Hazari ve Yitbarek, 2009). Kavram yanılgılarını gidermek oldukça zordur (Johnson, 1998b). Bunun en temel sebebi öğrencilerin var olan şemalarına yerleşmiş olan doğru olduğu düşünülen bilimsel temelleri olmayan bilgilerden kaynaklanmaktadır (Bozdağ, 2017). Bunun dışında farklı sebepler de bulunmaktadır. Bunlardan bir diğeri ise konu ile ilgili benzetmelerin ve kullanılan materyallerin gerçek tanımlar ve açıklamalar olarak algılanmasıdır (Stavy, 1991). Bu duruma örnek vermek gerekirse atom ve güneş sistemi birbirine benzetilmektedir. Sebebi ise ikisinde de yörüngenin olduğu ve atomda yörüngede elektronlar bulunurken güneş sisteminde gezegenlerin bulunması şeklinde düşünülmesidir. Bu tarz materyaller veya analojiler kullanılırken bunların sadece ortak yönleri değil farklı yönleri de verilmelidir. Ayrıca modellerin gerçeğin bir benzetimi olduğu ve bilimsel eksikliği açıklanmalıdır (Brown ve Clement, 1989). Kavram yanılgısının giderilmesini zorlaştıran diğer bir durum ise konu ile ilgili yapılan yüzeysel açıklamalardır. Konu anlatımlarında yüzeysel açıklamalar zamandan kazandırıyormuş gibi görünse de öğrencilerde kavram yanılgılarının oluşmasına sebep olmaktadır ve bu durum kavram yanılgılarının giderilmesini güçleştirmektedir (Barke vd., 2009).

Öğrenci konu ile ilgili kavram yanılgısına düştüğünü fark etmeksizin yanlış bildiği bilgiyi, düşünceyi veya kavramı doğruymuş gibi savunabilmektedir (Eryılmaz ve Tatll, 2001). $\mathrm{Bu}$ durumun ortadan kaldırılması için öğrenciler sahip oldukları kavram yanılgıları ile yüzleştirilmelidir. Öğretmen ders esnasında veya öncesinde konuyu anlatırken dikkatli davranarak öğrencilerde bulunan kavram yanılgılarını tespit ederse bunu hemen sınıf içerisinde bir tartışma ortamı oluşturarak gidermek için çabalayabilir. Bu sayede öğrenci hem kavram yanılgısıyla yüzleşir hem de zihinsel olarak edinilmiş olan kavram yanılgısının erkenden giderilme firsatı yakalanır (Campbell, Schwarz ve Windschitl, 2016).

Günlük hayatta sık sık karşımıza çıkan ve fen bilimleri dersinin bir konusu olan fiziksel ve kimyasal değişimler öğrenciler tarafindan derste kolay anlaşılır olduğu düşünülmesine rağmen sürekli birbiri ile karıştırılmaktadır (Nakiboğlu ve Erol, 2017). Bunun sebebi ise fiziksel ve kimyasal değişimler konusunun kavram yanılgısına açık olmasıdır. Fiziksel değişimler maddelerin çözünürlük, erime ve kaynama noktaları gibi özelliklerini dikkate alırken, kimyasal değişimler ise atomları bir arada tutan kimyasal bağların kopmasını olayı üzerinden temelde açıklanır (Taber, 2002a). Bu yüzden fen bilimlerinde konuyu basitleştirmek ve konunun mantığını oturtmak amacıyla fiziksel ve kimyasal değişimler çok farklı şekillerde ifade edilmektedir (Şen ve Nakiboğlu, 2018). Fiziksel ve kimyasal değişimler konusunda kavram yanılgılarının ortaya çıkmasında en çok öğrencilerin fiziksel ve kimyasal kavramlarını birbirinin zıttı olarak düşünmeleridir (Taber, 2002b). Genel olarak bakıldığında öğrencilerin fiziksel ve kimyasal değişim sonucu oluşan dönüşümleri tanecik boyutunda düşünememeleri de kavram yanılgılarına yol açmaktadır (Gensler, 1970). Öğrencilerin bu konudaki kavram yanılgıları giderilmez ise ileriye dönük olarak onların kimyasal reaksiyonlar, vb. konuları anlamalarında sorun yaşama potansiyelleri yüksek olacaktır. Bu sorun 2000'li yıllarda yapılan çalışmalardan itibaren yoğun olarak üzerinde durulan bir konu olmak ile birlikte hala bu konuda istenen farkındalık yeterli düzeyde oluşturulamamıştır (Del Pozo \& Porlan, 2001; Tsaparlis, 2003).

Kavram yanılgılarının tespitinde geçmişten bu yana çeşitli metotlar kullanılmıştır. Mülakatlar, açık uçlu ve çoktan seçmeli sınavlar, analojiler, eğitsel oyunlar, kavram haritaları gibi teknikler kullanılarak kavram yanılgıları tespit edilmeye çalışılmıştır (Bayraktar, 2009; Kaltakci-Gurel, Eryılmaz ve McDermott, 2015). Zamanla bu yöntemlerin kavram yanılgılarını tespit etme ve gidermede yeterli olmadığı düşüncesi eğitimcileri yeni metotlar geliştirmeye 
teşvik etmiştir (Kaltakci-Gurel, Eryilmaz ve McDermott, 2017). Son dönemlerde kavram yanılgılarının derinlemesine tespitinde üç aşamalı kavram yanılgısı testleri kullanılmaktadır (Gurcay ve Gulbas, 2015; Peşman ve Ery1lmaz, 2010; Kaltakci-Gurel vd., 2015). Çoktan seçmeli testlerin kavram yanılgılarını veya bilgi eksikliklerini tespit etmede yetersiz olması bu tür testlerin ortaya çıkmasında etkili olmuştur. Çoktan seçmeli testlerde öğrencilerin sorulara verdikleri doğru cevaplar, öğrencilerin konuyu eksiksiz bildikleri veya herhangi bir kavram yanılgısına sahip olmadıkları anlamına gelmemektedir. Öğrencilerin çoktan seçmeli testlerde sorulara doğru yanıt vermeleri şans faktörüyle de ilgili olabilir. Bu doğrultuda öğrencilerde var olan kavram yanılgıları teşhis edilememektedir (Aykutlu ve Şen, 2012).

Üç aşamalı kavram yanılgısı testi, öğrencilerin konuyu ne kadar bildiklerini, öğrencilerde oluşmuş olan kavram yanılgılarının tespitini ve öğrencilerin sorulara verdikleri cevaplardan emin olma durumlarını bir arada görme imkânı sağlar. Bu test öğrencilerin her aşamada verdikleri cevapların analiz edilmesiyle kavram yanılgılarının giderilmesinde oldukça önemli bir araçtır. Bu konu ile ilgili ilk çalışmalardan biri Treagust tarafindan yapılmıştır. Treagust öğrencilerde kavram yanılgılarının belirlenmesi için iki aşamalı bir kavram yanılgısı testi geliştirmiştir. Testin ilk aşamasını çoktan seçmeli sorular oluşturmaktadır. İkinci aşamasını ise öğrencilerin ilk aşamada vermiş oldukları cevabın nedenini yazdıkları kısım bulunmaktadır (Treagust ve Mann, 1998; Eryılmaz ve Peşman, 2010). Üç aşamalı kavram yanılgısı testinin iki aşamalı kavram yanılgısı testinden fark1, öğrencilerin sorulara verdikleri cevaplardan ve nedenlerinden emin olup olmadıklarını tespit etmek amacıyla eminim ve emin değilim seçeneklerinin de yer almasıdır.

Üç aşamalı kavram yanılgısı testine göre yanlış negatif bir kavram yanılgısına sahip bir ögrenci sorulara yanlış cevap verebilir ya da yanlış pozitif bir kavram yanılgısına sahip olan bir öğrenci sorulara doğru cevap verebilirler. Bu duruma örnek vermek gerekirse, bir öğrenci çoktan seçmeli kısımda doğru yanıt verirken sorunun nedenini yanlış açıklayabilir ve son kısımda emin olduğunu belirtebilir veya bir öğrenci çoktan seçmeli kısımda yanlış cevap verirken nedenini yanlış açıklayabilir ve son kısımda emin olmadığını belirtebilir. Örneği biraz daha açacak olursak öğrenci çoktan seçmeli kısımda soruya doğru yanıt verip nedenini yanlış yazıyorsa bu öğrencinin konu ile ilgili bilgi eksikliklerinin veya kavram yanılgısının olduğu anlamına gelebilir. Tam tersi durum söz konusu ise yani öğrenci çoktan seçmeli kısımda yanlış cevap verip nedenini doğru açıklıyorsa bu durum öğrencide kavram yanılgısı olduğu anlamına gelmez ve bu durum öğrencinin dikkat eksikliğinden kaynaklanmış olabilir (Peşman ve Ery1lmaz, 2010).

Yapılan çalışmada üç aşamalı kavram yanılgısı testinin kullanılması fen bilimleri öğretmen adaylarının fiziksel ve kimyasal değişimler konusundaki kavram yanılgılarını daha etkili bir şekilde belirlemeyi amaçlamaktadır. Bu kapsamda fiziksel ve kimyasal değişim ile ilgili olarak en yaygın olan 10 kavram yanılgısı belirlenmiş ve fen bilgisi öğretmen adaylarının bu kavram yanılgılarına sahip olup olmadıkları üç aşamalı kavram yanılgısı testi kullanılarak tespit edilmeye çalışılmıştır. Araştırma problemleri:

1. Fen bilgisi öğretmen adayları, fiziksel ve kimyasal değişimi doğru bir şekilde tanımlayabiliyorlar mı?

2. Fen bilgisi öğretmen adayları, fiziksel ve kimyasal değişim olup olmadığı öğrenciler tarafından zor belirlenen fiziksel veya kimyasal değişimleri doğru belirleyebiliyorlar mı?

\section{Yöntem}

$\mathrm{Bu}$ çalışmada betimsel araştırma türlerinden tarama yöntemi kullanılmıştır. Tarama yöntemi araştırılan konu hakkında katılımcıların görüş ve düşüncelerini, tutum, beceri gibi hususların belirlenmesinde kullanılan yöntemlerden biridir. Aynı zamanda tarama yöntemi büyük örneklemler üzerinde çalışmaya imkân tanıyan bir yöntemdir. Çalışmada veriler ölçek 
aracıllı̆ı ile toplanmış ve veri toplama aşamasından önce Afyon Kocatepe Üniversitesi Fen ve Mühendislik Bilimleri Bilimsel Araştırma ve Yayın Etiği Kurulundan 09.03.2021 tarih ve 12553 sayı numarası ile etik kurul izni alınmıştır.

\section{1. Örneklem}

Çalışma grubunu ortalama büyüklükte bir Anadolu şehrinde bulunan bir üniversitede öğrenim görmekte olan birinci, ikinci, üçüncü ve dördüncü sınıf fen bilgisi öğretmen adayları oluşturmaktadır. Çalışma, 35'i erkek ve 128'i kadın olmak üzere 163 öğretmen adayı ile yapılmıştır. Öğretmen adaylarından 45'i birinci sınıf, 61'i ikinci sınıf, 51'i üçüncü sınıf ve 6's1 dördüncü sınıftır. Çalışmanın bu kısmından sonra öğretmen adayları öğrenci olarak adlandırılacaktır.

Tablo 1. Örnekleme ait demografik özellikler

\begin{tabular}{llc}
\hline Değişkenler & & Katılımcı Sayıs1 (n=163) \\
\hline Cinsiyet & Kadın & 128 \\
& Erkek & 35 \\
Bölüm/ Sınıf & FBÖ 1 & 45 \\
& FBÖ 2 & 61 \\
& FBÖ 3 & 51 \\
YBÖ 4 & 6 \\
Yaş & 20 yaş altı & 35 \\
& 20 yaş & 42 \\
& 20 yaş üstü & 85 \\
& Boş & 1 \\
\hline
\end{tabular}

\subsection{Veri Toplama Aracı}

Veri toplama aracı olarak üç aşamalı bir kavram yanılgısı testi kullanılmıștır. Bu test alan yazında var olan yaygın 10 tane kavram yanılgısı belirlenerek oluşturulmuştur. Kavramsal tanımlamadaki eksiklikler kavram yanılgılarının oluşmasına neden olduğu için testin başına fiziksel ve kimyasal değişimin ne olduğunun tanımlanmasının istendiği bir bölüm eklenmiştir. Kullanılan testte katılımc1ların öncelikle ilgili konudaki ön bilgilerini görmek amacıyla fiziksel ve kimyasal değişimin kavramsal tanımlarını yazmaları istenmiştir. Daha sonra birinci aşamada öğretmen adaylarının konu hakkındaki kavram yanılgılarını belirlemek amacıyla fiziksel ve kimyasal değişim ile ilgili 10 tane kavram yanılgısı belirlenmiştir. Bu sorular yapılan alan yazın taraması sonucunda ögrenci, öğretmen adayları ve öğretmenlerin fiziksel ve kimyasal değişimler konusunda en çok tanımlamakta problem yaşadıkları kavram yanılgıları esas alınarak hazırlanmıştır.

$\mathrm{Bu}$ sorular üç aşamadan oluşmaktadır. İlk aşamada sorulan sorudaki değişimin fiziksel mi yoksa kimyasal mı olduğu katılımcılar tarafından işaretlenmesi beklenir (Tablo 2). İkinci aşamada katılımcılardan ilk aşamada verdikleri fiziksel veya kimyasal cevabının nedenini açık uçlu olarak yazmaları istenmiştir. Üçüncü ve son aşamada ise katılımcılar verdikleri cevapları eminim ya da emin değilim şeklinde belirtmeleri istenmiştir.

Tablo 2. Üç aşamalı kavram yanılgısı testinde kullanılan değişimlerin listesi

\begin{tabular}{clc}
\hline Sorular & & $\mathrm{F} / \mathrm{K}$ \\
\hline 1. & Buğdayıı un haline gelmesi & $\mathrm{F}$ \\
2. & Gökkuşağının oluşumu & $\mathrm{F}$ \\
3. & Elektriğin bakır tel üzerinden iletimi & $\mathrm{F}$ \\
4. & Ateş böceğinin ışı üretmesi & $\mathrm{K}$ \\
5. & Altından bilezik yapılması & $\mathrm{F}$ \\
6. & Gümüşün kararması & $\mathrm{K}$ \\
7. Naftalinin süblimleşmesi & $\mathrm{F}$ \\
8. & Hava yastığının şişmesi & $\mathrm{K}$ \\
9. & Mürekkebin su içinde dağılması & $\mathrm{F}$ \\
10. Çaya limon sıkılması & $\mathrm{K}$ \\
\hline
\end{tabular}

F: Fiziksel, K: Kimyasal 


\subsection{Veri Toplama Süreci}

Verilen ölçekler ortalama 10-15 dakika içerisinde tamamlanmıştır. Fen bilgisi öğretmenliği son sınıf öğrencileri sınav (KPSS) kaygılarından dolayı oldukça az oranda katılım göstermişlerdir. Katılım tamamen gönüllülük esasına göre gerçekleşmiştir.

\subsection{Verilerin Analizi}

Çalışma kapsamında elde edilen tüm veriler Microsoft Excel Programına kaydedilmiştir. Ölçeğin ön kısmında bulunan fiziksel ve kimyasal olayların tanımı kısmı için bir dereceli puanlama anahtarı oluşturulmuştur. $\mathrm{Bu}$ kısım geliştirilen üç basamaklı dereceli puanlama anahtarı ile değerlendirilerek " 0 " yanlış, "1" yarı doğru ve "2" tam doğru açıklama şeklinde puanlanmıştır. Ölçeğin ilk kısmında bulunan on soru da verilen örnek olaylar cevap anahtarına göre puanlanarak kodlanmıştır. İkinci kısımda yer alan olayın neden fiziksel veya kimyasal olduğu ile ilgili kısım ise yine geliştirilen üç basamaklı dereceli puanlama anahtarı ile değerlendirilerek "0" yanlış, "1" yarı doğru ve "2" tam doğru açıklama şeklinde puanlanmıştır. Son kısımda öğrencinin emin olması durumu "E" ile kodlanırken emin olmaması durumu " $D$ " ile kodlanmıştır.

\section{Bulgular}

Hazırlanan ölçeğin ön kısmında öğrencilerden fiziksel ve kimyasal değişimin tanımını yapmaları istenmiştir. Bu soruya verilen cevaplar ile ilgili bulgular aşağıda verilmiştir (Tablo 3).

Tablo 3. Fiziksel ve kimyasal değişim tanımlarına ait veriler

\begin{tabular}{lcccccc}
\hline Tanımlar & ${ }^{*} 0$ & $\mathrm{f} \%$ & ${ }^{*} 1$ & $\mathrm{f} \%$ & ${ }^{*} 2$ & $\mathrm{f} \%$ \\
\hline Fiziksel Değişim & 16 & $\% 9,81$ & 44 & $\% 26,99$ & 103 & $\% 63,19$ \\
Kimyasal Değişim & 18 & $\% 11,04$ & 130 & $\% 79,75$ & 15 & $\% 9,20$ \\
\hline
\end{tabular}

*0: yanlış, ${ }^{*} 1$ : yarı doğru, ${ }^{*} 2$ : tam doğru

Tablo 3'de görüldüğü üzere fen bilgisi öğretmenliği öğrencilerinin fiziksel değişim için kavramsal bir tanım yapmada kimyasal değişime göre daha başarılı oldukları görülmektedir. Kimyasal değişimin tanımını tam ve doğru olarak kavramsallaştırabilen öğrenci oranı \%10 gibi düşük bir değerdedir. Öğrencilerin fiziksel değişime ait yaptıkları tanımlardan bazıları şu şekildedir;

"Maddenin yapısı değişmeden sadece dış görünüşünde meydana gelen değişimlerdir" (Ö4).

"Bir maddenin dış yapısında meydana gelen, maddenin içyapısı değişmeyecek şekilde meydana gelen değişimlerdir” (Ö26).

Aynı öğrencilerin kimyasal değişimin tanımına verdikleri cevaplar ise şu şekildedir;

"Maddenin içyapısında meydana gelen değişmelerdir" (Ö4).

"Bir maddenin iç ve dış yapısında meydana gelen ve geri dönüşümü olmayan değişimlere denir" (Ö26).

Üç aşamalı olarak uygulanan fiziksel-kimyasal değişim kavram yanılgıları testinin analiz sonuçlarına baktığımızda birinci soru olan "buğdayın un haline gelmesi" sorusunun doğru olan fiziksel değişim cevabını veren 127, yanlış olan kimyasal değişim cevabını veren 36 öğrenci bulunmaktadır. Fiziksel değişim cevabını veren öğrencilerin 10'u yanlış cevap verirken 65'i yarı doğru ve 50'si ise tam doğru olarak cevaplamıştır. Fiziksel cevabı veren öğrencilerden 9 tanesi verdikleri cevaptan emin değildir. İlgili veriler aşağıdaki tabloda verilmiştir (Tablo 4). 
Tablo 4. Birinci soruya ait veriler

\begin{tabular}{|c|c|c|c|c|c|c|c|c|}
\hline \multirow[t]{2}{*}{$\mathrm{F} / \mathrm{K}$} & \multirow[t]{2}{*}{ Toplam } & \multicolumn{4}{|c|}{ Nedeni } & \multicolumn{3}{|c|}{ E/D } \\
\hline & & 0 & 1 & *2 2 & Boş & ${ }^{\alpha} \mathrm{E}$ & ${ }^{\alpha} \mathrm{D}$ & Boş \\
\hline${ }^{\beta}$ Fiziksel & 127 & 10 & 65 & 50 & 2 & 114 & 9 & 4 \\
\hline Kimyasal & 36 & 36 & - & - & - & 31 & 3 & 2 \\
\hline
\end{tabular}

${ }^{\beta}$ doğru cevap, ${ }^{*}$ 0: yanlış cevaplar, ${ }^{*}$ 1: yarı doğru cevaplar, ${ }^{*} 2$ : tam doğru cevaplar, ${ }^{\alpha} \mathrm{E}:$ eminim, ${ }^{\alpha} \mathrm{D}:$ emin değilim

$\mathrm{Bu}$ durum öğrenciler de bir kavram yanılgısının olduğuna işaret edebilir. Öğrencilerin bu soruya vermiş oldukları cevaplardan bazıları şu şekildedir;

"Buğday sadece çok küçük parçalara ayrılıyor. Bu yüzden fizikseldir." (Ö1)

“Çünkü buğdayın şekli değişmiyor.” (Ö14)

"Fiziksel yöntem kullanılan kimyasal olmaz." (Ö28)

Tablo 4'e baktığımızda kimyasal değişim cevabını veren 36 öğrenciden 29'u sorunun nedeninin açıklandığı kısımda kimyasal değişime göre açıklama yapmıştır. Burada en çok sorun yaşanan husus unun tekrar buğday haline getirilemeyecek olmasının düşünülmesinden kaynaklanmaktadır. Öğrencilerin bu soruya vermiş oldukları cevaplardan bazıları şu şekildedir;

"Un haline gelen buğday haline gelemez." (Ö25)

Tablo 5'e göre, "gökkuşağının oluşumu" sorusunun doğru cevabının fiziksel değişim olduğu ikinci soruyu ele alacak olursak ögrencilerden 137'si fiziksel, 26's1 kimyasal cevabını vermişlerdir.

Tablo 5. İkinci soruya ait veriler

\begin{tabular}{|c|c|c|c|c|c|c|c|c|}
\hline \multirow{2}{*}{$\mathrm{F} / \mathrm{K}$} & \multirow{2}{*}{ Toplam } & \multicolumn{4}{|c|}{ Nedeni } & \multicolumn{3}{|c|}{$\mathrm{E} / \mathrm{D}$} \\
\hline & & ${ }^{*} 0$ & * 1 & ${ }^{*} 2$ & Boş & ${ }^{\alpha} \mathrm{E}$ & ${ }^{\alpha} \mathrm{D}$ & Boş \\
\hline${ }^{\beta}$ Fiziksel & 137 & 36 & 48 & 46 & 7 & 117 & 14 & 6 \\
\hline Kimyasal & 26 & 20 & - & - & 6 & 17 & 7 & 2 \\
\hline
\end{tabular}

Fiziksel şıkkını işaretleyen öğrencilerin bu cevabı vermesi ile ilgili olarak yanlış, tam doğru ve yarı doğru yanıtların oranlarının birbirine çok yakın olduğu görülmektedir. Öğrencilerin verdikleri cevaplardan bazıları şunlardır;

"Yağmur yağdıktan sonra 1şı̆̆ın kırılmasıyla oluşan gökkuşağı fiziksel bir olaydır." (Ö3)

"Hava olayları fiziksel değişmedir." (Ö62)

"Herhangi bir kimyasal reaksiyon yoktur." (Ö37)

Burada dikkat çeken durum birçok öğretmen adayının 1şığın kırılmasını kimyasal değişim olarak düşünmeleridir. Bu hâlâ çok bilindik olduğu düşünülen olaylar ile ilgili kavram yanılgılarına sahip öğretmen adaylarımızın bulunduğunu göstermektedir.

Tablo 6'ya göre "bakır tel üzerinden elektrik iletimi" sorusunun doğru cevabı fiziksel olan üçüncü soruda 125 öğrenci fiziksel, 37 öğrenci kimyasal yanıtını vermiştir. Fiziksel cevabı vermesine rağmen nedenini yanlış açıklayan 47 öğrenci bulunmaktadır. Bu soruda birinci bölüme verilen cevapta şans faktörünün de etkisi olabileceğini yani öğrencilerin cevab1 bilmeden bir seçeneği seçmiş olabileceklerini gösteriyor. 
Tablo 6. Üçüncü soruya ait veriler

\begin{tabular}{lcccccccc}
\hline \multirow{2}{*}{ F/K } & \multirow{2}{*}{ Toplam } & \multicolumn{4}{c}{ Nedeni } & \multicolumn{3}{c}{ E/D } \\
\cline { 2 - 8 } & & 0 & ${ }^{*} 1$ & ${ }^{*} 2$ & Boş & ${ }^{\alpha} \mathrm{E}$ & ${ }^{\alpha} \mathrm{D}$ & Boş \\
\hline${ }^{\beta}$ Fiziksel & 125 & 47 & 77 & 28 & 10 & 124 & 23 & 12 \\
Kimyasal & 37 & 23 & 7 & 5 & 2 & 26 & 9 & 2 \\
\hline
\end{tabular}

${ }^{\beta}$ doğru cevap, ${ }^{*}$ 0: yanlış cevaplar, ${ }^{*} 1$ : yarı doğru cevaplar, ${ }^{*} 2$ : tam doğru cevaplar, ${ }^{\alpha} \mathrm{E}$ : eminim, ${ }^{\alpha} \mathrm{D}:$ emin değilim

$\mathrm{Bu}$ hususta öğrencilerde dirençli bir kavram yanılgısı bulunduğu gözlenmektedir. Öğrencilerin büyük çoğunluğu da verdikleri cevaptan emin olduklarını dile getirmişlerdir. Öğrencilerin bu soruya verdikleri cevaplardan bazıları şunlardır;

"Elektronların titreşimi sonucu elektrik iletilir. Olay fizikseldir.” (Ö3)

“Sürekli bir iletim söz konusudur ve elektron iletimi fizikseldir.”(Ö24)

"Elektriğin yapısında değişim olmaz." (Ö40)

"Bakır telin yapısına etki ettiği içindir" (Ö103)

Bu soru için ilginç olan durum şudur öğrencilerin 5 tanesi nedeni doğru açıklamalarına rağmen olayı kimyasal bir değişim olarak tanımlamış olmalarıdır. Bu öğrencilerin dikkatsizliğinden kaynaklanmış olabilir ve bu öğrenciler kavram yanılgısına sahip olmadığı çıkarımı yapılabilir. Ayrıca bu beş öğrencinin hepsi cevaptan emin olmadığını belirtmiştir. Buda ilgili çıkarımı desteklemektedir. Burada elektrik iletiminin kabloya nasıl bir etkisinin olacağının tam olarak kavranmamış olması da genel bir sorun olarak karşımızda durmaktadır.

Dördüncü soruya ait verilerin yer aldığı Tablo 7'ye göre “ateşböceğinin 1şık üretmesi” sorusunun doğru cevabının kimyasal olduğu ve 123 öğrencinin bu yanıtı verdiği görülmektedir. Öğrenciler soruya kimyasal cevabını vermelerine rağmen nedenini açıklamada öğrencilerin 16'sı tam doğru cevap verebilmiştir. Ateş böceğinde üretilen 1şığın doğal bir olay olduğunu düşünmelerinden dolayı 37 öğrenci bu soruya fiziksel cevabını vermiştir.

Tablo 7. Dördüncü soruya ait veriler

\begin{tabular}{lcccccccc}
\hline \multirow{2}{*}{ F/K } & \multirow{2}{*}{ Toplam } & \multicolumn{4}{c}{ Nedeni } & \multicolumn{3}{c}{ E/D } \\
\cline { 2 - 8 } & 37 & 0 & ${ }^{*} 1$ & ${ }^{*} 2$ & Boş & ${ }^{\alpha}$ E & ${ }^{\alpha} \mathrm{D}$ & Boş \\
\hline Fiziksel & 123 & 25 & 2 & - & 10 & 21 & 13 & 3 \\
${ }^{\beta}$ Kimyasal & 43 & 44 & 16 & 20 & 88 & 25 & 10 \\
\hline${ }^{\beta}$ doğru cevap, ${ }^{*}$ 0: yanlış cevaplar, ${ }^{*}$ 1: yarı doğru cevaplar, ${ }^{*}$ 2: tam doğru cevaplar, ${ }^{\alpha}$ E: eminim, ${ }^{\alpha}$ D: emin \\
değilim
\end{tabular}

Burada da görüldüğü üzere 37 öğrenciden fiziksel cevabını vermesine rağmen yarı doğru denebilecek cevapları veren 2 öğrencinin bulunmasıdır. Öğrencilerin bu soruya verdikleri yanıtlardan bazıları şu şekildedir;

“Ateşböceği kimyasal bir reaksiyon sonucu 1şık saçar.”(Ö29)

"Çünkü böceğin yapısında buna neden bazı maddelerin reaksiyonu olduğunu hatırliyorum." (Ö54)

“Ateşböceği üstüne gelen 1şı̆̆ yansitmıştır.”(Ö82)

“Kendiliğinden 1ş1k ürettiği için fizikseldir.”( Ö10)

Tablo 8'de bakıldığında "altından bilezik yapımı" sorusunun doğru cevabının fiziksel olduğunu öğrencilerin büyük çoğunluğu belirtmişlerdir. 15 öğrenci yanlış 67 öğrenci yarım ve 48 öğrenci ise tam doğru olarak neden kısmında açıklamada bulunmuşlardır. 
Tablo 8. Beşinci soruya ait veriler

\begin{tabular}{lcccccccc}
\hline \multirow{2}{*}{ F/K } & \multirow{2}{*}{ Toplam } & \multicolumn{4}{c}{ Nedeni } & \multicolumn{3}{c}{ E/D } \\
\cline { 2 - 9 } & & 0 & ${ }^{*} 1$ & ${ }^{*} 2$ & Bos & ${ }^{\alpha} \mathrm{E}$ & ${ }^{\alpha} \mathrm{D}$ & Boş \\
${ }^{\beta}$ Fiziksel & 139 & 15 & 67 & 48 & 9 & 120 & 11 & 8 \\
Kimyasal & 24 & 20 & 1 & - & 3 & 16 & 6 & 2 \\
\hline
\end{tabular}

${ }^{\beta}$ doğru cevap, 0 : yanlış cevaplar, " 1 : yarı doğru cevaplar, ${ }^{*}$ 2: tam doğru cevaplar, ${ }^{\alpha} \mathrm{E}$ : eminim, ${ }^{\alpha} \mathrm{D}$ : emin değilim

Yanlış olan kimyasal cevabını ise 24 öğrenci vermiştir. 24 öğrenciden sadece 1 tanesinin açıklaması yarı doğrudur. Öğrencilerin verdikleri yanıtlardan bazıları şu şekildedir;

“Altının şekil ve görüntüsünü değiştirdik. Bu yüzden fizikseldir.” (Ö5)

“Eski haline dönebilir.”( Ö117)

"Alaşımlardan dolayıdır." (Ö120)

“Maddenin yapısında olan değişmedir.”(Ö104)

Tablo 9'a göre "gümüşün kararması” olan altıncı soruda öğrencilerin büyük çoğunluğu doğru cevap olan kimyasal değişim cevabını vermişlerdir.

Tablo 9. Altınc1 soruya ait veriler

\begin{tabular}{lcccccccc}
\hline \multirow{2}{*}{ F/K } & \multirow{2}{*}{ Toplam } & \multicolumn{4}{c}{ Nedeni } & \multicolumn{4}{c}{ E/D } \\
\cline { 2 - 9 } & & 0 & ${ }^{*} 1$ & ${ }^{*} 2$ & Boş & ${ }^{\alpha} \mathrm{E}$ & ${ }^{\alpha} \mathrm{D}$ & Boş \\
\hline Fiziksel & 24 & 16 & 5 & 2 & 1 & 16 & 3 & 5 \\
${ }^{\beta}$ Kimyasal & 139 & 25 & 80 & 31 & 3 & 125 & 8 & 6 \\
\hline${ }^{\beta}$ doğru cevap, ${ }^{*}$ 0: yanlış cevaplar, ${ }^{*}$ 1: yar doğru cevaplar, ${ }^{*}$ 2: tam doğru cevaplar, ${ }^{\alpha} \mathrm{E}$ : eminim, ${ }^{\alpha}$ D: emin \\
değilim
\end{tabular}

Kimyasal cevabını veren öğrencilerin nedenlerini açıklamada 25 öğrencinin yanlış, 80 öğrencinin yarı doğru ve 31 öğrencinin tam doğru olarak cevaplandırdıkları görülmektedir. Öğrencilerin bu soruya verdikleri yanıtlardan bazıları şu şekildedir;

"Gümüşün kararması kimyasaldır. Gümüş havadaki oksijenle tepkimeye girerek kararma meydana gelir.” (Ö7)

"Gümüşün atom ve molekül yapısı değiştiği için kimyasaldır." (Ö78)

"Güneş ş̧ığında gümüşün yapısındaki bileşiklerin yapısının değişmesidir. (Ö12)

"Gümüş karardığı zaman gümüşs suyuyla tekrar açılabilir. Gümüş özelliğini kaybetmez." (Ö6)

Tablo 10'da yer alan bilgiler doğrultusunda "naftalinin süblimleşmesi" sorusunda öğrencilerden 127'si fiziksel 35'i kimyasal cevabını vermişlerdir. Öğrencilerin büyük çoğunluğu soruyu tam doğru olarak cevaplamışlardır.

Tablo 10. Yedinci soruya ait veriler

\begin{tabular}{lcccccccc}
\hline \multirow{2}{*}{ F/K } & \multirow{2}{*}{ Toplam } & \multicolumn{4}{c}{ Nedeni } & \multicolumn{3}{c}{ E/D } \\
\cline { 2 - 9 } & & ${ }^{*} 0$ & ${ }^{*} 1$ & ${ }^{*} 2$ & Boş & ${ }^{\alpha} \mathrm{E}$ & ${ }^{\alpha} \mathrm{D}$ & Boş \\
${ }^{\beta}$ Fiziksel & 127 & 9 & 29 & 84 & 5 & 106 & 10 & 11 \\
Kimyasal & 35 & 25 & 7 & 1 & 2 & 21 & 9 & 5 \\
\hline
\end{tabular}

${ }^{\beta}$ doğru cevap, ${ }^{*}$ 0: yanlış cevaplar, ${ }^{*}$ 1: yarı doğru cevaplar, ${ }^{*}$ 2: tam doğru cevaplar, ${ }^{\alpha} \mathrm{E}$ : eminim, ${ }^{\alpha} \mathrm{D}$ : emin değilim

35 öğrencinin ise yanlış olan kimyasal cevabını verdiği görülmektedir. Yarı ve tam doğru cevapların toplamında 8 öğrencinin bu hususta yanlış şıkkı işaretlemiş olma ihtimali vardır. 25 öğrenci de ise kavram yanılgılarının olduğu göze çarpmaktadır. Öğrencilerin bu soru için verdikleri yanıtlardan bazıları şu şekildedir; 
“Çünkü hal değişimi olayları fizikseldir. Fiziksel olaylar eski haline dönüşür. Katı halden gaz haline ssı alarak geçtiği gibi hal değişim olayları da 1sı vererek eski katı haline gelir." (Ö76)

“Maddenin sadece diş görünüşünde değişme olur.”( Ö110)

"Havaya karışır." (Ö152)

"Naftalin süblimleştiğinde havaya karışır. Tekrar elde etme imkânımız yoktur. Laboratuvar ortamında belli düzeneklerle süblimleştirdiğimizde tekrar elde edebiliriz." (Ö70)

Üç aşamalı kavram yanılgısı testinde yer alan "hava yastı̆̆ının şişmesi”" sorusunda öğrencilerin çoğunluğunun fiziksel değişim cevabı verdikleri görülmektedir. 33 öğrenci doğru olan kimyasal değişim cevabını vermiştir. Aşağıda Tablo 11'i incelenirse hava yastığının şişmesi olayının kimyasal sürecinden haberdar olmadıkları anlaşılmaktadır. Bu soruda ilginç olan 129 fiziksel cevabını veren öğrenciden 95 kişinin cevabından da emin olmasıdır.

Tablo 11. Sekizinci soruya ait veriler

\begin{tabular}{|c|c|c|c|c|c|c|c|c|}
\hline \multirow[b]{2}{*}{$\mathrm{F} / \mathrm{K}$} & \multirow[b]{2}{*}{ Toplam } & \multicolumn{4}{|c|}{ Nedeni } & \multicolumn{3}{|c|}{$\mathrm{E} / \mathrm{D}$} \\
\hline & & ${ }^{*} 0$ & * 1 & 2 & Boș & ${ }^{\alpha} \mathrm{E}$ & ${ }^{\alpha} \mathrm{D}$ & Boş \\
\hline Fiziksel & 129 & 102 & 17 & - & 10 & 95 & 23 & 11 \\
\hline${ }^{\beta}$ Kimyasal & 33 & - & 7 & 19 & 7 & 22 & 9 & 2 \\
\hline
\end{tabular}

Kimyasal cevabını vermesine rağmen 7 öğrencinin bu sorunun açıklama kısmını boş bıraktığı görülmektedir. Öğrencilerin bu soruya verdikleri cevaplardan bazıları şu şekildedir;

"Hava yastığının yapısında hiçbir değişiklik olmaz. Sadece hacmi büyür, şeklinde değişiklik olur.” (Ö68)

"Etki-tepki ile olur. Herhangi bir kaza anında darbe ile hava yastığı açılır.” (Ö100)

“Elementler ve kimyasal değişim olmadığı için fizikseldir." (Ö127)

“Orada bir kimyasal reaksiyon sonucu bir şişme olduğu içindir.” (Ö114)

Tablo 12'ye göre öğrencilerin çoğunluğu "mürekkebin su içinde dağılması" sorusuna doğru olan fiziksel değişim cevabını vermelerine rağmen 48 öğrencinin nedenini açıklama kısmında tam bir bilimsel açıklama yapamadığı görülmektedir. 41 öğrencinin kimyasal yanıtını verdiği soruda 3 öğrenci yarı doğru bir şekilde bir açıklama vermiştir. 34 öğrencinin bu soru için kavram yanılgısına net bir şekilde sahip oldukları görülmektedir.

Tablo 12. Dokuzuncu soruya ait veriler

\begin{tabular}{|c|c|c|c|c|c|c|c|c|}
\hline \multirow{2}{*}{$\mathrm{F} / \mathrm{K}$} & \multirow{2}{*}{ Toplam } & \multicolumn{4}{|c|}{ Nedeni } & \multicolumn{3}{|c|}{$\mathrm{E} / \mathrm{D}$} \\
\hline & & *0 & $* 1$ & *2 & Boş & ${ }^{\alpha} \mathrm{E}$ & ${ }^{\alpha} \mathrm{D}$ & Boş \\
\hline${ }^{\beta}$ Fiziksel & 121 & 48 & 44 & 17 & 12 & 87 & 28 & 6 \\
\hline Kimyasal & 41 & 34 & 3 & - & 4 & 19 & 15 & 7 \\
\hline
\end{tabular}

Öğrencilerin bu soruya verdikleri yanıtlardan bazıları şu şekildedir;

"Mürekkep su içinde dağıldığında suyun görünümü değişir. Bu yüzden fiziksel bir olaydır." (Ö3)

"Mürekkebin yapısında suyla birleştiği için karışım oluşturulduğundan fizikseldir." (Ö127)

"Mürekkep su içinde dağılır ve seyrelir." (Ö115) 
Tablo 13'de yer alan "çaya limon sıkılması" sorusunda doğru cevabın kimyasal olduğu son soruda öğrencilerden 14'ü yanlış, 39'u yarı doğru ve 27'si tam doğru olarak nedenlerini açıklamışlarıdır. Burada öğrencilerin bilimsel açıklamalar yapma konusunda sıkıntıları olduğu görülmektedir.

Tablo 13. Onuncu soruya ait veriler

\begin{tabular}{|c|c|c|c|c|c|c|c|c|}
\hline \multirow{2}{*}{$\mathrm{F} / \mathrm{K}$} & \multirow{2}{*}{ Toplam } & \multicolumn{4}{|c|}{ Nedeni } & \multicolumn{3}{|c|}{$\mathrm{E} / \mathrm{D}$} \\
\hline & & ${ }^{*} 0$ & *1 & *2 2 & Boş & ${ }^{\alpha} \mathrm{E}$ & ${ }^{\alpha} \mathrm{D}$ & Boş \\
\hline Fiziksel & 71 & 51 & 8 & 4 & 8 & 53 & 13 & 5 \\
\hline${ }^{\beta}$ Kimyasal & 90 & 14 & 39 & 27 & 10 & 52 & 31 & 7 \\
\hline
\end{tabular}

Öte yandan Tablo 13'e bakıldığında 71 öğrencinin de fiziksel olarak cevap verdikleri belirtilmiştir. Tablodan 51 öğrencide kavram yanılgısının var olduğu dikkati çekmektedir. Bu kadar yüksek oranda öğrencinin yanlış cevap vermesi öğrencilerin temel bilgilerinde eksikliklerin olabileceğini gösterebilir.

Öğrencilerin bu soruya verdikleri cevaplardan bazıları şu şekildedir;

"Çay ve limon farklı maddeler olduğu için limon içindeki asit çayın rengini açıyor ve bu olay kimyasaldır.” (Ö5)

"Birbirlerinin yapısına karıştı̆̆ından kimyasaldır." (Ö12)

"İçerisindeki maddelerin yapısı değişir." (Ö29)

"Çaya limon sıkılması fizikseldir. Çünkü çaya limon sıkıldığında ayın sadece rengi biraz açılmıştır. Biraz da tadında bir değişme olmuştur." (Ö7)

\section{Tartışma}

Kavram öğretimi ve bu öğretimin getirdiği bazı zayıflıklardan doğduğu düşünülen kavram yanılgıları çok uzun yıllardır fen araştırmalarının odağında kalmıştır. Bunun temel nedenlerinden biri kavram yanılgılarının giderilmesinin oldukça zor olmasıdır (Gil- Perez ve Carrascosa, 1990). Kavram yanılgılarının toplandığı ve detaylıca tartışıldığı bir çok bilimsel çalışma bulunmaktadır (Allen, 2014; Barke vd., 2009; Kovács, Csupor, Lente ve Gunda, 2014; Taber, 2002a; 2002b). Bu çalışmalara rağmen kavram öğretimi hala üzerinde durulması gereken önemli bir husustur (İpekcioglu, Elmas, Geban ve Yesilyurt, 2011). Özellikle öğretmen merkezli bir öğrenme anlayışından öğrenen merkezli bir anlayışa doğru ilerleyen süreçte kavram yanılgılarının azalacağı ve büyük oranda üstesinden gelineceği düşülmüştür. Ancak öğretmenlerin, öğrenci merkezli yöntemler konusunda uzun süreli meslek içi eğitim desteği alamamaları, bu dönüşümün tam olarak yansımasına engel olmuş ve kavram yanılgılarının önemli bir problem olarak devam etmesine neden olmuştur(Elmas, Öztürk, Irmak ve Cobern, 2014). Güncel çalışmalara baktığımızda kavram yanılgıları ile ilgili problemlerin tam olarak çözülemediği de açık bir şekilde görülmektedir (Çalgıcı, Yıldırım ve Duru, 2020; Peker ve Taş, 2020).

$\mathrm{Bu}$ çalışma da belirlenen ikinci bir temel sorunda kavram yanılgılarını fiziksel veya kimyasal olarak doğru cevaplayan öğrenciler bile, temel bilgi eksikliklerinden kaynaklı basit günlük olaylara tatmin edici düzeyde bilimsel açıklamalar getirememektedirler. Bulgular kısmındaki tablolar incelendiğinde özellikle verilen sekiz tane değişimin öğrenciler tarafından büyük oranda fiziksel veya kimyasal olarak doğru sınıflandırıldığı ama nedeninin bilimsel kavram ve terimleri kullanarak ifade edilemediği belirlenmiştir. $\mathrm{Bu}$ durum alan yazında özellikle öğrencilerin bilimsel açıklamaları içi yeterli argüman üretememeleri şeklinde farklı çalışmalarda da bulunmuştur (Sandoval ve Millwood, 2005; McNeill, 2011). Bazı öğretmenlerin de sınıf içi tartışma ve bilimsel açıklamalar kullanılmasını yeterince destekleyemediğini bilinmektedir (Sampson ve Blanchard, 2012). Bu durumun nedenlerinden biri öğrencilerin günlük hayattan olayların bağlam olarak kullanıldığı etkili bir fen eğitimi almamış olmaları 
olabilir (Elmas ve Geban, 2016). Günlük hayattan öğrencilerin ilgisini çeken bağlamlar, sorular veya sorunlar üzerinden kurgulanan bir eğitim anlayışı bu sorunu çözmeye destek olabilir (Bülbül, Elmas ve Eryılmaz, 2019; Demircioğlu, Dinç ve Calik, 2013; Elmas, Akın ve Geban, 2013; Elmas, 2020). Eğitsel bağlamın öğrencilerin bilimsel argüman kalitesini sözlü ve yazınsal olarak artırdığını rapor eden çalışmalar vardır (Berland ve McNeill, 2010).

$\mathrm{Bu}$ çalışma kapsamında belirlenerek sorulan fiziksel ve kimyasal değişimlerin doğru belirlenmesinde öğrencilerin sorun yaşadıkları önemli noktalardan biri geri dönüştürülebilir olma veya olmama ile ilgili olan durumdur (Kabapınar ve Adik, 2005). Bu konu öğretilirken veya öğretmen ile birlikte bu konu ile ilgili etkinlikler yapılırken geri dönüştürülebilme/dönüşebilme gibi ifadelerin kullanılması fiziksel ve kimyasal değişimlerin anlaşılmasını zorlaştırıyor gibi görünmektedir. Mesela bu çalışma da sorulan buğdayın un haline gelmesi sorusunda öğrenciler, un tekrar buğday haline dönemez, bu sebeple kimyasal bir değişimdir diye cevap vermişlerdir. Öğrencileri daha çok tanecik (atom veya moleküller) düzeyinde düşünmeye teşvik etmek bu sorunu çözme de bize yardımcı olabilir.

Öğrencilerin büyük çoğunluğu fiziksel değişimin tanımını doğru yapmalarına rağmen kimyasal değişim tanımını yarı doğru olarak cevaplamıştır. Fiziksel ve kimyasal değişim tanımlarına verilen cevaplardan yola çıkarak bu hususta yapılan diğer çalışmalara bakıldığında benzer sonuçlara rastlanmaktadır. Eilks, Moellering and Valanides (2007), yaptıkları çalışmada bu çalışmadakine benzer şekilde öğrencilerin fiziksel ve kimyasal değişimi birbirinin tersi olarak düşündükleri ve ayrı ayrı bu kavramları yeterince anlamlandıramadıkları bulgusuna ulaşmıştır.

$\mathrm{Bu}$ çalışma kapsamında sorularda kullanılan hava yastığının şişmesi veya çaya limon sıkılması gibi değişimleri öğrenciler kimyasal olarak sınıflandırmakta güçlük çekmişlerdir. Buradaki her iki sınıflandırmada nettir. Bazı sınıflandırmaları yapmak gerçekten güç olabilir mesela yapılan bazı çalışmalarda tuzun suda çözünmesi gibi fiziksel mi kimyasal mı olduğu daha tartışmalı durumlar öğretmenler tarafından da farklı şekillerde değerlendirilerek bazen ikilem durumları oluşmaktadır (Gensler, 1970; Taber, 2002a; 2002b). Tuzun suyun içinde iyonlarına ayrışmasından dolayı moleküller düzeyde düşünüldügünde farklı şekillerde yorumlanabilecek değişimler ve olaylar kullanılacaksa öğrencilere açıklamaların net bir şekilde yapılması önemlidir.

Soruları incelediğimizde ilk soru olan buğdayın un haline gelmesi sorunun doğru cevabı fiziksel olmasına rağmen bu soruya kimyasal cevabını veren öğrenciler bulunmaktadır. Alanyazında bulunan fiziksel ve kimyasal değişim çalışmalarından Ayvacı ve ŞenelÇoruhlu'nun (2009) yaptıkları çalışmada bulunan kavram yanılgılarından biri de ezilme ve öğütme işlemlerinin öğrenciler tarafindan maddenin kimyasının değiştiğini düşünmelerinden dolayı bu durumu kimyasal olarak algılamalarıdır. Bunun bir diğer nedeni de toz haline gelmiş buğdayın geri döndürülemeyeceğini ve tekrar bir bütün buğday tanesi oluşturulamayacağını düşünmeleridir. İkinci soru olan gökkuşağı oluşumu sorusunun verileri incelendiğinde sorunun doğru cevabı fiziksel olmasına rağmen öğrencilerden az bir kısmı kimyasal cevabı vermiştir. Gökyüzü olaylarının olması doğal olarak meydana gelemez algısından kaynaklanan bir durum olabilir (Değirmenci ve Karamustafaoğlu, 2018). Öğrencilerin cevapları bu yönde vermeleri gökkuşağ1 oluşumunda kimyasal tepkimelerin olduğunu düşünmelerinden kaynaklanıyor olabilir. Öte yandan optik ve ışığın kırılması konusundan getirdikleri kavram yanılgıları da olabilir.

Üçüncü soru olan bakır telden elektrik iletimi sorusu incelendiğinde alanyazında yer alan araştırmalardan hareketle öğrenciler elektrik konusunda oldukça fazla kavram yanılgısına sahip olduğu görülmektedir. (Eryılmaz ve Peşman, 2010)'un çalışmalarında da benzer bir durum söz konusudur. Buradaki muhtemel temel sebep öğrencilerin iletim olaylarını ve elektrik üretimini kimyasal olarak düşünmeleri olabilir. Dördüncü soru da öğrenciler ateş böceğinin 1 ş̧1k üretmesi sorusunun cevabı kimyasal olmasına rağmen fiziksel cevabını vermelerinin altında 
yatan sebep bu durumun böceğin vücudunda kendiliğinden gerçekleşen bir olay olarak düşünmeleridir. Çakır ve Uludağ (2019)'un çalışmalarından da hareketle öğrenciler doğal olan her şey fizikseldir algısına kapılarak bu cevabı vermiş olabilirler.

Beşinci soruda altından bilezik yapımını öğrencilerin büyük çoğunluğu fiziksel cevabını vererek doğru yanıtlamışlardır fakat bu soruya öğrencilerin yarı doğru cevap veren öğrenciler de yer almıştır. Demircioğlu, Özmen ve Demircioğlu (2006)'nın çalışmasında da yer aldığı üzere maddenin diş yüzeyinde olan her şey fizikseldir diye düşünülmektedir. Altıncı soru olan gümüşün kararması oksitlenme olayından dolayı kimyasal olmasına rağmen öğrencilerden az sayıda fiziksel cevabı verenler bulunmaktadır. Fiziksel değişim olarak cevap veren öğrencilerin böyle düşünmelerindeki sebep maddenin dış görünüşünün değişmesi ve maddenin yüzeyindeki değişimin giderilebilir olarak algılanması olabilir. Bu duruma benzer örnekler alanyazında da yer almaktadır. Geban ve Kıngır (2014)'ın yaptığı çalı̧̧mada öğrencilerin fiziksel ve kimyasal değişim ile ilgili kavram yanılgıları incelenmiş olup çalışmada bazı kavram yanılgıları tespit edilmiştir. Bu çalışmada yer alan kavram yanılgılarından biri de öğrencilerin fiziksel değişimde sadece maddenin dış görünüşünün değiştiğini düşünmeleridir. Bu konunun ele alındığı bir başka çalışma ise Eilks, Moellering ve Valanides (2007)'nin çalışması olup, bu çalışmada öğrencilerin kimyasal değişimin geri döndürülemez olduğunu düşünmeleri olduğu vurgulanmıştır. Yapılan çalışmada öğrenciler her ne kadar bu soruya kimyasal cevabını verseler bile nedenini açıklamada yetersiz kalmışlardır. Bunun sebebi de kimyasal değişime uğrayan bir madde asla eski haline getirilemez algısından kaynaklanmaktadır.

Yedinci soru olan naftalinin süblimleşmesi bir hal değişimi olayıdır ve fizikseldir. $\mathrm{Bu}$ soruya öğrencilerin kimyasal değişim cevabı vermelerinin nedeni hal değişimlerinin kimyasal olarak gerçekleştiğini düşünmeleri olabilir. Ayrıca Çayan ve Karslı (2015)'in çalışmalarında da olduğu üzere öğrenciler hal değişimi olaylarını kimyasal bir süreç geçirdiklerini düşünmektedirler. Sekizinci soruda hava yastığının şişmesi olayında öğrencilerin fiziksel olarak nitelendirmelerinin sebebi çok muhtemelen hava yastığının şişmesi için gerçekleşen kimyasal reaksiyondan haberdar olmamalarıdır. Aslında birçok genel kimya kitabında günlük hayat ile ilişki kurmak amacıyla bu tarz örnekler verilmekte ve oluşan kimyasal olaylar açıklanmaktadır.

Dokuzuncu soru olan mürekkebin su içinde dağılması olayında öğrencilerin mürekkebin su içinde dağılmasının bir karışım olduğunu, eski haline dönemez olduğunu ve bu durumu kimyasal olarak algılamaları olabilir. Öğrencilerin verdikleri cevaplar dikkate alındığında mürekkep ile suyun birbiri ile karışım oluşturduğunu düşünen öğrencilerin de olduğu görülmektedir. Son soru olan onuncu soruda çaya limon sıkılmasını öğrencilerin bir kısmının çayın renginin değişmesinden dolayı kimyasal, bir kısmının da çayın yapısının değişmemesinden dolayı fiziksel olarak ele almalarıdır (Şen ve Nakipoğlu, 2018). Çaya limon sıkılmasını öğrencilerden bazıları birbiri içinde çözünme olarak düşünerek cevap vermişlerdir. Bazı öğrenciler de çay ve limonun birbiri içinde reaksiyon verdiğini söylemişlerdir.

Yapılan çalışmadan hareketle kavram yanılgılarının belirlenmesi için üç aşamalı kavram yanılgısı testinin kullanımı etkili sonuçlar vermiştir. Bu testin en güçlü yanı öğrencide yer alan kavram yanılgısını tespit etmekle birlikte öğrencinin konuyu ne düzeyde hâkim olduğunun anlaşılmasını da sağlamasıdır. Ayrıca tahmin ederek değişimleri sınıflandırmak yetmemiş mutlaka doğru açıklamayı da yapmak gerekmiştir. Dört aşamalı ölçme araçları da bir sonraki adım olarak geliştirilmiştir (Kaltakci-Gurel vd., 2017). Eminlik indeksi öğrencinin kavram yanılgısı ile ilgili olarak ne kadar ısrarcı olabileceği ile ilgili bir gösterge olarak da değerlendirilebilir. Öğrencinin kavram yanılgısına sahip olması ve bundan emin olması öğrencide kavramsal bir değişim yaratmak için oldukça büyük bir direnç olduğu ile ilgili bir kanittır.

$\mathrm{Bu}$ çalışma betimsel bir çalışma olduğu ve sadece bir üniversitedeki fen bilgisi öğretmen adayları ile çalışıldığı için çalışma sonuçları dikkatle değerlendirilmelidir. Çalışmanın sonuçları gönüllülük esasına dayandığı için bütün resmi tam olarak yansıttığını söylemek de 
mümkün olmayabilir. Bu şekilde kavram yanılgılarını belirlemeye dönük çalışmaların kapsamlı üç veya dört aşamalı ölçme araçları ile yapılmaya devam edilmesi önem arz etmektedir. Kavram yanılgılarının dirençli olduğu bilindiğine göre sınıf içinde yapılan eğitim ve öğretimin kavram yanılgısı oluşumunu engelleyecek kalitede yapılması benzer olumsuzlukların önüne geçecektir. $\mathrm{Bu}$ noktada öğretmen eğitiminin öğretmenlerin devamlı desteklenecekleri şekilde yapılanması ve belli periyotlar ile tekrarlı bir şekilde eğitilmeleri ile aşılabilir. $\mathrm{Bu}$ eğitimleri ile öğretmenlerin öğrenci merkezli eğitim yaklaşım ve yöntemlerini kullanmaları kavram yanılgılarının desteklenmesi sürecine destek olabilir.

\section{Kaynakça}

Abimbola, I. O., \& Baba, S. (1996). Misconceptions \& alternative conceptions in science textbooks: The role of teachers as filters. The American Biology Teacher, 58(1),14-19.

Allen, M. (2014). Misconceptions in primary science. McGraw-hill education (UK).

Aykutlu, I. \& Şen, A. İ. (2012). Üç aşamalı test, kavram haritası ve analoji kullanılarak lise öğrencilerinin elektrik akımı konusundaki kavram yanılgılarının belirlenmesi. Eğitim ve Bilim, 37(166), 275-288.

Ayvacı, H. Ş. \& Şenel-Çoruhlu, T. (2009). Fiziksel ve kimyasal değişim konularındaki kavram yanılgılarının düzeltilmesinde açıklayıcı hikâye yönteminin etkisi. On Dokuz Mayıs Üniversitesi Eğitim Fakültesi Dergisi, 28, 93-104.

Barke, H. D., Hazari, A., \& Yitbarek, S. (2009). Students' misconceptions and how to overcome them. In Misconceptions in Chemistry (pp. 21-36). Springer, Berlin, Heidelberg.

Bayraktar, S. (2009). Misconceptions of Turkish pre-service teachers about force and motion. International Journal of Science and Mathematics Education, 7(2), 273-291.

Berland, L. K., \& McNeill, K. L. (2010). A learning progression for scientific argumentation: Understanding student work and designing supportive instructional contexts. Science Education, 94(5), 765-793.

Bolat, Y \& Dolapçığlu, S. (2020). Kavram öğretimi sürecinin "bil, anla, yap" boyutları bağlamında değerlendirilmesi. Bolu Abant İzzet Baysal Üniversitesi Eğitim Fakültesi Dergisi, 20(1), 61-80.

Bozdağ, H. C. (2017). Üç aşamalı kavramsal ölçme aracı ile öğrencilerin sindirim sistemi konusundaki kavram yanılgılarının tespiti. Bartın Üniversitesi Eğitim Fakültesi Dergisi, 6(3), 878-901.

Brown, D. E., \& Clement, J. (1989). Overcoming misconceptions via analogical reasoning: Abstract transfer versus explanatory model construction. Instructional science, 18(4), 237261.

Bülbül, M. Ş., Elmas, R., \& Eryılmaz, A. (2019). Fizik ve kimya disiplinleri için ilgi çekici olan bağlamların bağlam disiplin ilişkisi kapsamında belirlenmesi. Mehmet Akif Ersoy Üniversitesi Ĕ̈itim Fakültesi Dergisi, (50), 451-479.

Campbell, T., Schwarz, C., \& Windschitl, M. (2016). What we call misconceptions may be necessary stepping-stones toward making sense of the world. Science and Children, 83(3), 69-74.

Chandrasegaran, A. L., Treagust, D. F., \& Mocerino, M. (2007). The development of a two-tier multiple-choice diagnostic instrument for evaluating secondary school students' ability to describe and explain chemical reactions using multiple levels of representation. Chemistry Education Research and Practice, 8(3), 293-307. 
Cho, H., Kahle, J. B., \& Nordland, F. H. (1985). An investigation of high school biology textbooks as a source of misconceptions and difficulties in genetics and some suggestions for teaching genetics. Science Education 69(5), 707-719.

Çakır, Ç. Ş., \& Uludağ, G. (2019). Okul öncesi dönemdeki çocukların "1ş1k” kavramına ilişkin bilgilerinin belirlenmesi. Ankara Üniversitesi Eğitim Fakültesi Dergisi 52(1), 163 - 189.

Çalgıc1, G., Y1ldırım, M. \& Duru, M. K. (2020). Elimination by gamification the 5th grade students' misconceptions about the matter and phase change. Necatibey Faculty of Education Electronic Journal of Science \& Mathematics Education, 14(2), 1278-1310.

Çayan, Y., \& Karsl1, F. (2015). 6. Sınıf öğrencilerinin fiziksel ve kimyasal değişim konusundaki kavram yanılgılarının giderilmesinde probleme dayalı öğrenme yaklaşımının etkisi. Kastamonu Ĕgitim Dergisi, 23(4), 1437-1452.

Değirmenci, S., \& Karamustafaoğlu, O. (2018). Kitap incelemesi: doğru bilinen yanlışlardan, yanlış bilinen doğrulara: Fizikte kavram yanılgıları. Elementary Education Online, 17(3), 518.

Demircioğlu, G., Özmen, H., \& Demircioğlu, H. (2006). Sınıf öğretmeni adaylarının fiziksel ve kimyasal değişme kavramlarını anlama düzeyleri ve yanılgıları. Milli Ĕgitim Dergisi, 170(35), 260-273.

Demircioğlu, H., Dinç, M., \& Calik, M. (2013). The effect of storylines embedded within context-based learning approach on grade 6 students' understanding of physical and chemical change concepts. Journal of Baltic Science Education, 12(5), 682-691.

Eggen, P. \& Kauchak, D. (2004). Educational psychology: Windows, classrooms. Upper Saddle River: Pearson Prentice Hall.

Eilks, I., Moellering, J., \& Valanides, N. (2007). Seventh-grade students' understanding of chemical reactions: Reflections from an action research interview study. Eurasia Journal of Mathematics, Science \& Technology Education, 3(4), 271-286.

Elmas, R. (2020). Bağlamın anlamı ve nitelikleri ve öğrencilerin fen eğitiminde bağlam tercihleri. Turkiye Kimya Dernegi Dergisi Kısım C: Kimya Egitimi, 5(1), 53-70.

Elmas, R., \& Geban, Ö. (2016). The effect of context based chemistry instruction on 9th grade students' understanding of cleaning agents topic and their attitude toward environment. Ë̆itim ve Bilim, 41(185), 33-50.

Elmas, R., Akın, F. N., \& Geban, Ö. (2013). Ask a scientist website: trends in chemistry questions in Turkey. The Asia-Pacific Education Researcher, 22(4), 559-569.

Elmas, R., Öztürk, N., Irmak, M., \& Cobern, W. W. (2014). An investigation of teacher response to national science curriculum reforms in Turkey. International Journal of Physics \& Chemistry Education, 6(1), 2-33.

Ergül, S., Sarıtaş, D., \& Özcan, H. (2020). Hipotetik TGA (Tahmin-Gözlem-Açıklama) döngüsü ile kimyasal değişimin doğasının öğretimi; asit-baz indikatör tepkimesi örneği. Balıkesir Üniversitesi Fen Bilimleri Enstitüsü Dergisi, 22(2), 490-506.

Eryılmaz, A., \& Tatlı, A. (2001). Geleneksel öğretim yönteminin ODTÜ öğrencilerinin Mekanik dersindeki kavram yanılgılarına etkisi. Eğitim ve Bilim, 26(122), $72-77$.

Gensler, W. J. (1970). Physical versus chemical change. Journal of Chemical Education, 47(2), 154-155.

Gil-Perez, D., \& Carrascosa, J. (1990). What to do about science "misconceptions". Science Education, 74(5), 531-540. 
Gurcay, D., \& Gulbas, E. (2015). Development of three-tier heat, temperature and internal energy diagnostic test. Research in Science \& Technological Education, 33(2), 197-217.

İpekcioglu, S., Elmas, R., Geban, O., \& Yesilyurt, H. (2011). Effectiveness of conceptual change instruction on fluid force topic. In INTED2011 Proceedings (pp. 1482-1487). IATED. 5th International Technology, Education and Development Conference, 7-9 March, Valencia, Spain.

Johnson, P. (1998a). Children's understanding of changes of state involving the gas state, Part 1: Boiling water and the particle theory. International Journal of Science Education, 20(5), 567-583. doi: 10.1080/0950069980200505

Johnson, P. (1998b). Children's understanding of changes of state involving the gas state, Part 2: Evaporation and condensation below boiling point. International Journal of Science Education, 20(6), 695-709. doi: 10.1080/0950069980200607

Kabapınar, F. M. \& Adik, B. (2005). Ortaöğretim 11.sınıf öğrencilerinin fiziksel değişim ve kimyasal bağ ilişkisini anlama seviyesi. Ankara Üniversitesi Eğitim Bilimleri Fakültesi Dergisi, 38(1), 123-147.

Kaltakci-Gurel, D., Eryilmaz, A. \& McDermott, L. C. (2015). A review and comparison of diagnostic instruments to identify students' misconceptions in science. Eurasia Journal of Mathematics, Science \& Technology Education 11(5), 989-1008.

Kaltakci-Gurel, D., Eryilmaz, A. \& McDermott, L. C. (2017) Development and application of a four-tier test to assess pre-service physics teachers' misconceptions about geometrical optics, Research in Science \& Technological Education, 35(2), 238-260.

Kingir, S., \& Geban, Ö. (2014). 10th grade students' conceptions about chemical change. Journal of Turkish Science Education, 11(1), 43-62.

King, C. J. H. (2010). An analysis of misconceptions in science textbooks: Earth science in England and Wales. International Journal of Science Education, 32(5), 565-601.

Kirbulut, Z. D., \& Geban, O. (2014). Using three-tier diagnostic test to assess students' misconceptions of states of matter. Eurasia Journal of Mathematics, Science and Technology Education, 10(5), 509-521.

Kovács, L., Csupor, D., Lente, G., \& Gunda, T. (2014). 100 chemical myths: Misconceptions, misunderstandings, explanations. Springer.

Martin, R., Sexton, C. and Gerlovich, J. (2002). Teaching science for all children: Methods for constructing understanding. Boston: Allyn and Bacon.

McNeill, K. L. (2011). Elementary students' views of explanation, argumentation, and evidence, and their abilities to construct arguments over the school year. Journal of Research in Science Teaching, 48(7), 793-823.

Nakhleh, M. B. (1992). Why some students don't learn chemistry: Chemical misconceptions. Journal of Chemical Education, 69(3), 191-196.

Nakiboğlu, C., \& Erol, N. (2017). Deneyimli kimya öğretmenlerinin fiziksel ve kimyasal değişimler konusunun öğretimi ile ilgili düşünceleri. Muğla Sıtkı Koçman Üniversitesi Eğitim Fakültesi Dergisi, 4(1), 33-45.

Papageorgiou, G., Stamovlasis, D., \& Johnson, P. M. (2010). Primary teachers' particle ideas and explanations of physical phenomena: effect of an in-service training course. International Journal of Science Education, 32(5), 629-652. 
Peker, E. A. \& Taş, E. (2020). 5. Sınıf öğrencilerinin "Canlılar dünyasını gezelim ve tanıyalım" ünitesi ile ilgili kavram yanılgıları. Yüzüncü Yll Üniversitesi Ĕgitim Fakültesi Dergisi, 17(1), 643-670.

Peşman, H., \& Eryılmaz, A. (2010). Development of a three-tier test to assess misconceptions about simple electric circuits. The Journal Of Educational Research, 103(3), 208-222.

Sampson, V., \& Blanchard, M. R. (2012). Science teachers and scientific argumentation: Trends in views and practice. Journal of Research in Science Teaching, 49(9), 1122-1148.

Sandoval, W. A., \& Millwood, K. A. (2005). The quality of students' use of evidence in written scientific explanations. Cognition and instruction, 23(1), 23-55.

Sneider, C., Bar, V., \& Kavanagh, C. (2011). Learning about Seasons: A Guide for teachers and curriculum developers. Astronomy Education Review, 10(1), 1-22.

Stavy, R. (1991). Using analogy to overcome misconceptions about conservation of matter. Journal of Research in Science Teaching, 28(4), 305-313.

Şen, A. Z., \& Nakiboğlu, C. (2018). Deneyimli kimya öğretmenlerinin alan eğitimi bilgisi temelinde ölçme bilgilerinin fiziksel-kimyasal değişimler konusu kapsamında belirlenmesi. Necatibey Ĕgitim Fakültesi Elektronik Fen ve Matematik Ĕgitimi Dergisi, 12(2), 698-726.

Şenel Çoruhlu, T., \& Çepni, S. (2015). "Güneş sistemi ve ötesi: Uzay bilmecesi" ünitesinde karşılaşılan öğretmen problemleri ve yanılgıları: Bir özel durum çalışması. Journal of Theoretical Educational Science/Kuramsal Eğitimbilim Dergisi, 8(2), 268-281.

Taber, K. S. (2002a). Chemical misconceptions - prevention, diagnosis and cure: Classroom resources (Vol. 2). London: Royal Society of Chemistry.

Taber, K. S. (2002b). Chemical misconceptions - prevention, diagnosis and cure: Theoretical background (Vol. 1). London: Royal Society of Chemistry.

Taylor, A. K., \& Kowalski, P. (2004). Naive psychological science: The prevalence, strength, and sources of misconceptions. The Psychological Record, 54(1), 15-25.

Treagust, D. F. (1988). Development and use of diagnostic tests to evaluate students' misconceptions in science. International Journal of Science Education, 10(2), 159-169.

Treagust, D. F., \& Mann, M. (1998). A pencil and paper instrument to diagnose students' conceptions of breathing, gas exchange and respiration. Australian Science Teachers Journal, 44(2), 55-59.

Yates, T. B., \& Marek, E. A. (2014). Teachers teaching misconceptions: a study of factors contributing to high school biology students' acquisition of biological evolution-related misconceptions. Evolution: Education and Outreach, 7(1), 1-18.

Yip, D. (1998). Identification of misconceptions in novice biology teachers and remedial strategies for improving biology learning. International Journal of Science Education, 20(4), 461-477.

\section{ETIKK ve BİLIMSEL İLKELER SORUMLULUK BEYANI}

$\mathrm{Bu}$ çalışmanın tüm hazırlanma süreçlerinde etik kurallara ve bilimsel atıf gösterme ilkelerine riayet edildiğini yazar(lar) beyan eder. Aksi bir durumun tespiti halinde Afyon Kocatepe Üniversitesi Sosyal Bilimler Dergisi'nin hiçbir sorumluluğu olmayıp, tüm sorumluluk makale yazarlarına aittir. Yazarlar etik kurul izni gerektiren çalışmalarda, izinle ilgili bilgileri (kurul adı, tarih ve sayı no) yöntem bölümünde ve ayrıca burada belirtmişlerdir. 
Kurul adı: T.C. Afyon Kocatepe Üniversitesi Fen ve Mühendislik Bilimleri Bilimsel Araştırma ve Yayın Etiği Kurulu

Tarih: 09.03.2021

No: 12553

ARAŞTIRMACILARIN MAKALEYE KATKI ORANI BEYANI

1. yazar katkı oranı : \% 60

2. yazar katkı oranı : $\% 40$ 